Original Research Paper

\title{
Feasibility Study on Solar Power Plant Utility Grid under Malaysia Feed-in Tariff
}

\author{
${ }^{1}$ M. Pauzi M. Kassim, ${ }^{2}$ Karam M. Al-Obaidi, ${ }^{3}$ M. Arkam C. Munaaim and ${ }^{4}$ Abd. Mokhti Salleh \\ ${ }^{1}$ Faculty of Electrical Engineering, Universiti Teknologi Malaysia, 81310, Johor, Malaysia \\ ${ }^{2}$ Faculty of Built Environment, University of Malaya, 50603 Kuala Lumpur, Malaysia \\ ${ }^{3}$ School of Environmental Engineering, Universiti Malaysia Perlis, 02600, Perlis, Malaysia \\ ${ }^{4}$ School of Electrical System Engineering, Universiti Malaysia Perlis, 02600, Perlis, Malaysia
}

Article history

Received: 27-03-2015

Revised: 19-05-2015

Accepted: 27-05-2015

Corresponding Author:

M. Arkam C. Munaaim

School of Environmental

Engineering, Universiti

Malaysia Perlis, 02600, Perlis,

Malaysia

Email: arkam@unimap.edu.my

Karam M. Al-Obaidi

Faculty of Built Environment

University of Malaya, 50603

Kuala Lumpur, Malaysia

Email: karam_arc@yahoo.com

\begin{abstract}
In Perlis, Northern Malaysia, a solar power plant with an energy capacity of $5 \mathrm{MWp}$ began selling energy to Tenaga Nasional Berhad in January 2013. Upon obtaining Feed-in Tariff approval from the Sustainable Energy Department Authority of Malaysia, the power plant will produce energy with a Feed-in Tariff of RM 0.874 for every kWh for 21 years according to the Renewable Energy Power Purchase Agreement. However, the output of solar plants is unpredictable. Investors commonly estimate the output of solar PV power generation from simulation results based on irradiation data proposed in simulations. However, estimates of potential solar generation from simulated analyses may not be accurate and thus exert negative financial impacts to investors. Therefore, comparing estimated output results from simulations with the actual output from solar PV power generation is important. The aim of the present study is to identify the error between the simulation and actual performance of solar PV power generation over the twelve months of 2013. Sensitivity analysis of Feed-in Tariff degression was also performed to study the impact the performance error on the economic aspect of energy generation.
\end{abstract}

Keywords: Solar Power, Plant Utility Grid, Feed-In Tariff, Malaysia

\section{Introduction}

The environment and energy crises are major issues worldwide. The release of greenhouse gases, especially $\mathrm{CO}_{2}$ from power generation using coal, gas and steam, depletes the ozone layer and creates more pollution. Shortages in fossil fuels and increasing energy demands also contribute to the energy crisis. The world depends on fossil fuels as primary sources of energy. Some projections indicate that the global energy demand will triple by 2050 (MP, 2011). Globally in 2010, 86.9\% of the total energy usage involved fossil fuels, where $33.5 \%$ of the energy usage was from crude oil, $23.8 \%$ was from natural gas and the remaining was from coal. On the other hand, $5.22 \%$ was from nuclear energy, $6.46 \%$ was from hydroelectric energy and $1.3 \%$ was from renewable energy (BP, 2011).

In Malaysia, the Primary Energy Demand (PED) is represented by natural gas $60.3 \%$, coal $30.4 \%$, hydroelectric power $5.4 \%$ and crude oil $1.1 \%$ (Daud, 2010). Major concerns in using fossil fuels as primary energy have been expressed. GHG emissions and fossil fuel depletion, for example, are among the major issues in fossil fuel usage. In Malaysia, researchers estimate that 339 million tons of $\mathrm{CO}_{2}$ will be produced by 2030 . According to the APEC (2009), the energy sector is the biggest contributor of $\mathrm{CO}_{2}$ emissions (GHG, 42\%) to the atmosphere at, followed by the transportation sector (28\%) and the industrial sector (20\%). The Malaysian government has grown increasingly concerned about GHG emissions and fossil fuel depletion. When the energy demand increases, GHG emissions and the demand for fossil fuels increase accordingly. In 2009, Malaysia introduced the National Green Technology Policy, which is designed to mitigate issues of security, energy efficiency and environmental impact while addressing the rising energy demand.

Given that environmental protection concerns are increasing worldwide, both new energy and clean fuel technologies are being intensively pursued and investigated. Most renewable energy sources, including wind, microhydro, tidal, geothermal, biomass and solar, are converted into electrical energy for delivery either directly to the 
utility grid or to isolated loads (Canale et al., 2009; Mercure and Salas, 2012).

Solar energy technologies, including solar heating, solar Photovoltaic (PV) cells, solar thermal electricity and solar architecture can make significant contributions toward solving some of the most pressing energy problems currently faced by the world. PV technology has been proven to generate electricity from solar energy easily. Malaysia is a country in which renewable energy is widely promoted because of its tropical location. The country receives an average solar irradiation of $400-600 \mathrm{MJ} / \mathrm{m}^{2}$ per month and thus has potential for establishing large-scale solar power generation plants (Mekhilef et al., 2012).

The solar potential and Feed-in Tariff (FiT) rate offered by the Malaysian government to energy producers is expected to attract more investors to the renewable power generation sector, which in turn will help the government achieve its objective of promoting clean technology. The Malaysian government is keen to develop solar energy as a significant source of energy in the country. According to the 10th National RE Goals, a large allocation of funds has been allocated to the implementation of solar PV systems, as shown in Fig. 1.

The size of a power supply system exerts an important function when generating electricity in farflung areas at a reasonable price. PV systems and other renewable energy systems are excellent options for producing energy at low-to-medium power levels in remote areas because of easy scaling of the input power source (Chamboulegron, 1986; Enslin, 1990). The main feature of PV systems is that they can produce electric power without harming the environment. PV systems achieve this by directly transforming a free inexhaustible source of energy, namely, solar energy, into electricity.
Continuing decreases in the cost of PV arrays and increases in their efficiency also promote the use of PV generating systems (Zweibel, 1990; Hussein et al., 1995).

PV systems may be categorized as a grid-connected PV systems, stand-alone PV systems, or building systems. In grid-connected applications, DC power from solar cells runs through an inverter, which feeds the power back into the distribution system. Grid-connected systems have proven their worth in natural disasters by providing emergency power capabilities during utility power interruptions. While the PV power generated by this type of system is generally more expensive than utility-provided power, the use of grid-connected systems is increasing (Penick and Louk, 1998; Quesada et al., 2011). Various technologies, such as silicon PV (crystalline silicon and nanocrystalline), thin film solar cells (amorphous silicon, cadmium telluride, gallium arsenide and copper indium gallium deselenide) and concentrated PV (multifunction cells), are used to produce PV cells. Of these technologies, researchers have found that multicrystalline outputs and monocrystalline cells have the highest output range (between 12 and 17\%) (Sick and Erge, 1996).

PV systems are known to present varying seasonal patterns that depend on temperature and solar irradiation. PV system outputs vary because of the different temperature coefficients of the voltage and current output. To simplify the work of manufacturers, PV modules are rated at standard test conditions of a solar irradiation of $1000 \mathrm{Wm}^{-2}$, fixed spectrum and sun-spectrum at air mass of $1.5(\mathrm{AM}=1.5)$. The electric power generated by a solar PV array fluctuates depending on the operating conditions and a number of field factors, such as the sun's geometric location, irradiation levels and ambient temperature (KeTTHA, 2011).

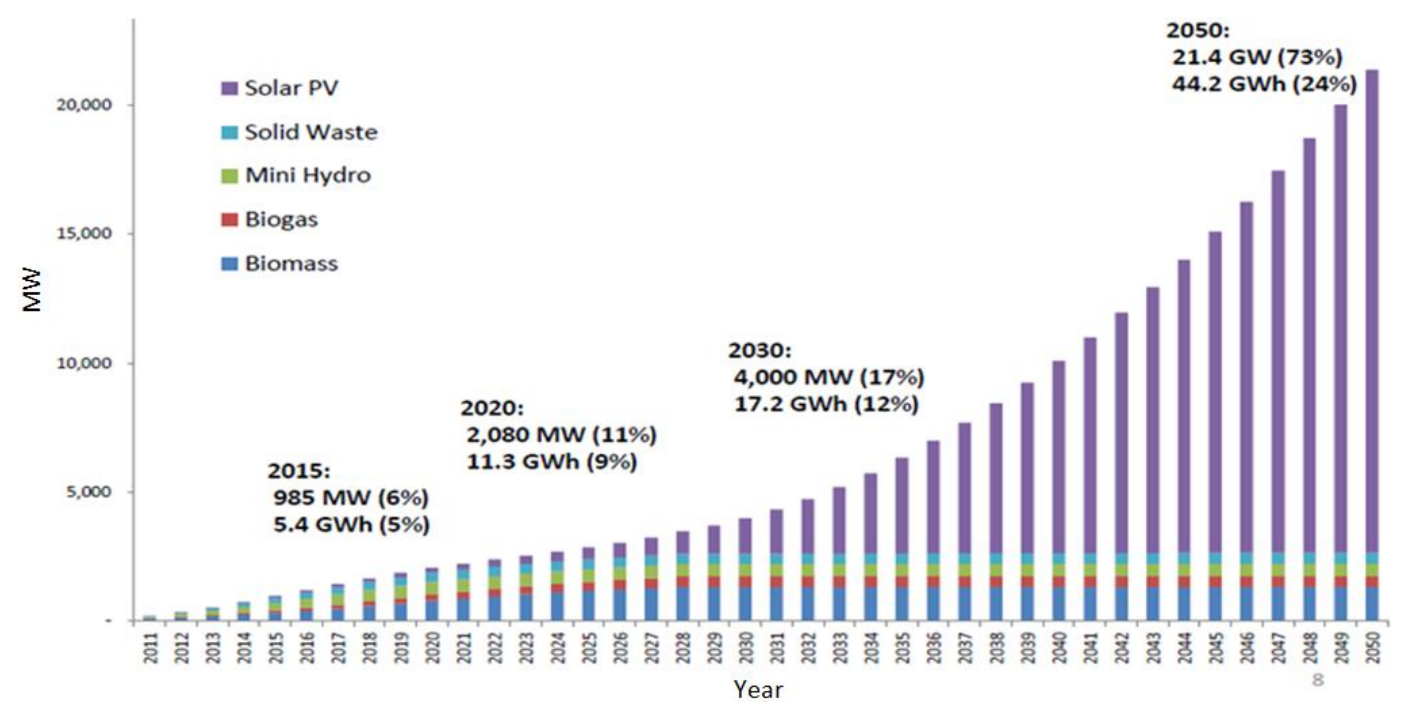

Fig. 1. National renewable energy Goals of the Sustainable Energy Development Authority (SEDA) (Source: Sustainble Energy Developement Authority Malaysia) 
The study initially reviewed the performance of previous solar PV power generation systems but found that a large number of studies on this topic and a detailed review are beyond the scope of this research. Mondal and Sadrul Islam (2011) conducted a case study in Bangladesh where they identified the potential location of grid-connected solar PV in 14 districts. The study analyzed the feasibility of $1 \mathrm{MWp}$ solar PV using HOMER optimization software. However, this study was discontinued because of very high investment costs. Thus, a comparison based on actual performance and the results of simulation analysis could not be performed to confirm findings.

Another solar PV performance analysis was conducted by Sharma and Chandel (2013). Performance analysis of a $190 \mathrm{kWp}$ solar PV power plant installed in Khatkar-Kalan, India, was carried out and simulation estimations were found to be in close agreement with the actual measured results with an uncertainty of $1.4 \%$. This estimation was performed using PVSYST software. Detailed analysis of the plant's economic feasibility, however, was not performed.

To promote green energy, many countries have introduced the concept of Feed-in Tariff (FiT) for renewable energy. The FiT scheme has been proven successful in accelerating RE deployment, reducing carbon emissions and creating jobs in different countries, such as Germany, Italy, Spain and Thailand (Chua et al., 2011). FiTs are RE payments of electricity in kilowatthour $(\mathrm{kWh})$. FiT promotes exportation of electricity as a form of investment. The concept of FiT, according to the Ministry of Energy, Green Technology and Water, obliges Distribution Licensees (DLs) to buy the electricity produced from renewable sources from feedin approval holders and sets a feed-in rate. DLs thus pay for each unit of renewable electricity supplied to the grid for a specific duration (GPS, 2012).

FiT was introduced to encourage more people to invest in renewable energy sources. The introduction of FiT is set to change Malaysia's electricity production through RE. Domestic and industrial users will be able to generate renewable electricity (i.e., solar power) through RE and sell it back to the national power grid at a premium rate (NEB, 2008). Solar PV power generation is still new in Malaysia and thus requires a large initial investment.

Therefore, feasibility studies focusing on the economic impact of the initial costs of solar PV power are necessary. The first solar power plant under the FiT scheme was inaugurated on March 28, 2012 by Cypark Resources Berhad. The power plant had a total investment of RM 100 million and a capacity output of 8 MWp (GPS, 2012). With the successful construction of this solar power plant, the Malaysian government achieved a significant milestone in promoting clean energy in the country. Given that the development of large solar power sources in Malaysia requires large investments and that solar generation power plants under the FiT scheme are a new concept, prospective investors were initially doubtful. The fact that case planning-based simulations were not completely parallel with actual expectations also caused doubt. In the present study, we analyzed differences between simulation analysis results and actual production to identify sources of discrepancies. By identifying the difference percentage, investors are likely to feel more confident about investing in the renewable energy generation sector of Malaysia. The study objective is to determine the technical and economic feasibility of solar power plant generation in Malaysia.

\section{Methodology}

In this study, the solar PV power plant, located in Perlis, Malaysia (latitude $6^{\circ} 24^{\prime}$ North and longitude $100^{\circ} 8^{\prime}$ East), uses poly-crystalline panels, as shown in Fig. 2. An install capacity of $5 \mathrm{MWp}$ was used as the case study. Information for economic analysis, such management planning stage and price of materials (e.g., solar PV modules, inverters and land acquisition), was gathered from a consulting solar PV company (Mega Jati Consult Sdn. Bhd). The FiT rates in Malaysia are shown in Table 1.

Several design tools to model and simulate the performance of PV power generation systems are available in the market. The present study was implemented so that actual results can be compared with the analysis of simulation software. The study also presents an overview of the extent of GHG emissions and economic impact of a degression of $8 \%$ per year of FiT, as offered by Malaysia. By studying FiT degression, an indicator of future investments in RES in Malaysia may be obtained to ensure that the objectives of the country are achieved.

Simulation software has been developed to estimate the performance of a solar power plant and assist system designers and installers (Henrion et al., 2013). HOMER is a computer model that simplifies the task of evaluating design options for both off-grid and grid-connected power systems for remote, stand-alone and distributed generation applications (Homer Energy). Three main tasks can be performed by HOMER: Simulation, optimization and sensitivity analysis. HOMER was developed by the United States National Renewable Energy Laboratory and is specifically designed to analyze and optimize renewable energy industry systems, as applied by (Mondal and Sadrul Islam, 2011; Bhattacharjee and Dey, 2014).

HOMER is mostly used for studying, sizing and analyzing the performance of PV grid-connected systems. It is useful for determining several aspects in terms of finance, such as net present value and cost of energy. 

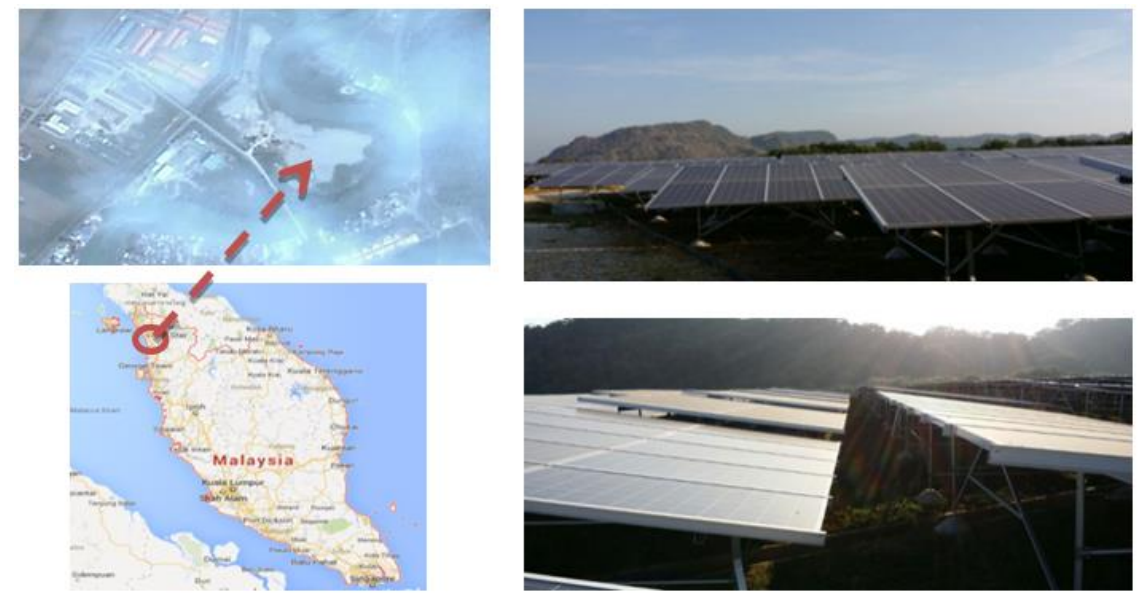

Fig. 2. Solar power plant (Perlis, Malaysia)

Table 1. FiT rates

\begin{tabular}{lllll}
\hline Renewable energy & Installed capacity (Mwh) & Cost (RM) & Effective period (Years) & Annual degression rate \\
\hline Solar PV & 5 & 0.874 & 21 & $8 \%$
\end{tabular}

The variation of input parameters, such as FiT or solar radiation can be performed to identify the different outputs for each input. In this study, HOMER was used to predict the total monthly and yearly energy output of a $5 \mathrm{MWp}$ grid interactive component of the PV plant.

The study is divided into two parts: The technical analysis and the economic analysis. The difference between the actual and simulated PV outputs of the solar plant was examined and analyzed to identify the error. Cost analysis refers to the total system cost, which includes initial and maintenance costs. The annual cost was calculated to determine the life cycle cost and payback period. All costs were based on real prices used in the development of the solar power plant.

\section{Technical Analysis}

\section{Measurement of Actual Data}

The actual data, such as solar radiation and energy production, were collected based on site measurement to compare the actual performance of the system against HOMER simulation. The solar PV power plant was equipped with the latest Supervisory Control and Data Acquisition System (SCADA), as shown in Fig. 3.

Parameters such solar radiation and electrical energy production were recorded and averaged at $15 \mathrm{~min}$ intervals by the data logger. The recorded data were stored in a computer system using an RS232/RS485 peripheral interface with a SCADA communicator through a computer.

\section{Simulation Data}

\section{Solar Radiation}

Solar radiation is radiant energy that can be converted into electrical energy by solar PV panels. This parameter input was important to ensure the success of solar PV power generation because every location on earth receives different amounts of solar radiation. In HOMER, the data were generated by adding the latitude and longitude of the solar plant location.

\section{Modeling of the Solar PV Power Generation}

In this study, the SEDA-approved grid connected to the solar PV system was $5 \mathrm{MWp}$. All of the energy produced by the solar PV power plant was injected into the grid system without any limit from the utility provider (Tenaga Nasional Berhad). HOMER simulation was based on the maximum output and all electrical instruments, such as the solar PV and inverter, were calibrated accordingly to meet the maximum output (Fig. 4).

\section{Solar PV Array}

The kilowatt $(\mathrm{kW})$ capacity was determined using HOMER. Based on a maximum output of $5 \mathrm{MWp}$, the size of the solar PV was $5 \mathrm{MW}$ (Fig. 5). In terms of economic analysis, the capital cost for the solar PV was RM 38,550,048.00. The projected cost covered all components except for the inverter. Other parameters considered in this study were slope degree, derating factor, ground reflector and solar PV lifetime; these parameters were proposed by HOMER.

The cost of replacement was assumed to be the same as the initial costs. Another parameter to be considered is Operation and Maintenance (O\& M), which is reflected by the salary of one Electrical Charge man amounting to RM 48,000.00 per year. 


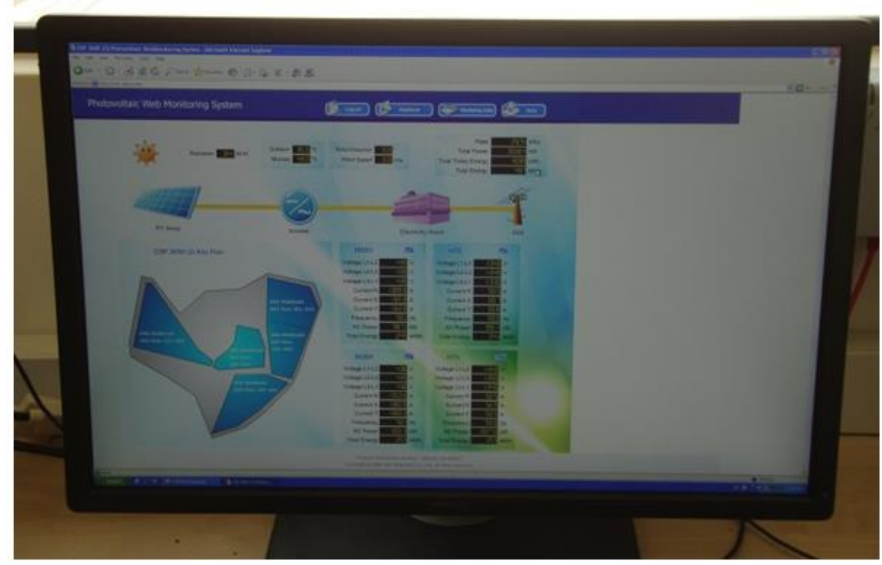

Fig. 3. SCADA system used for monitoring and recording purposes

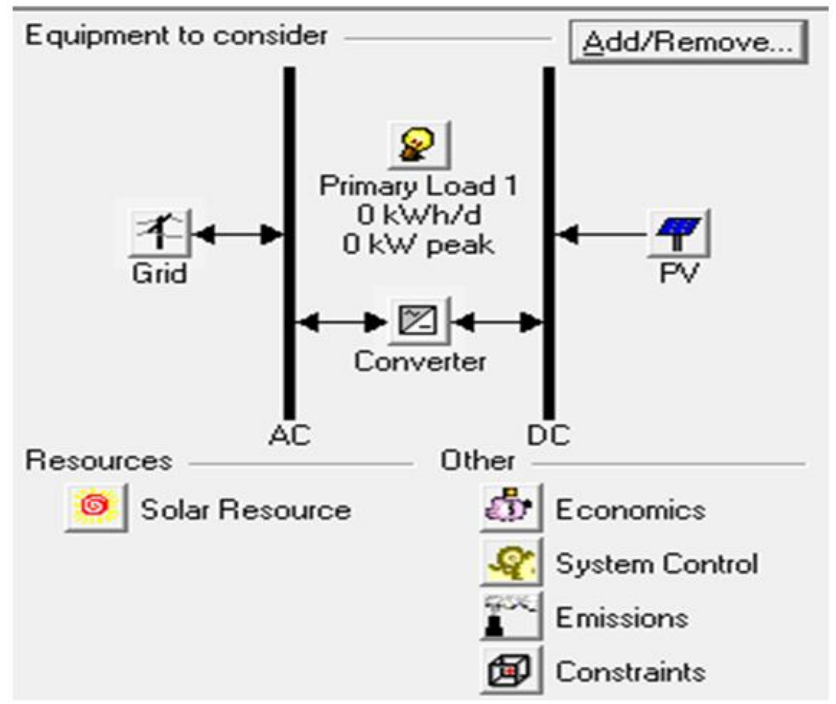

Fig. 4. Solar PV grid-connected system modeling by HOMER

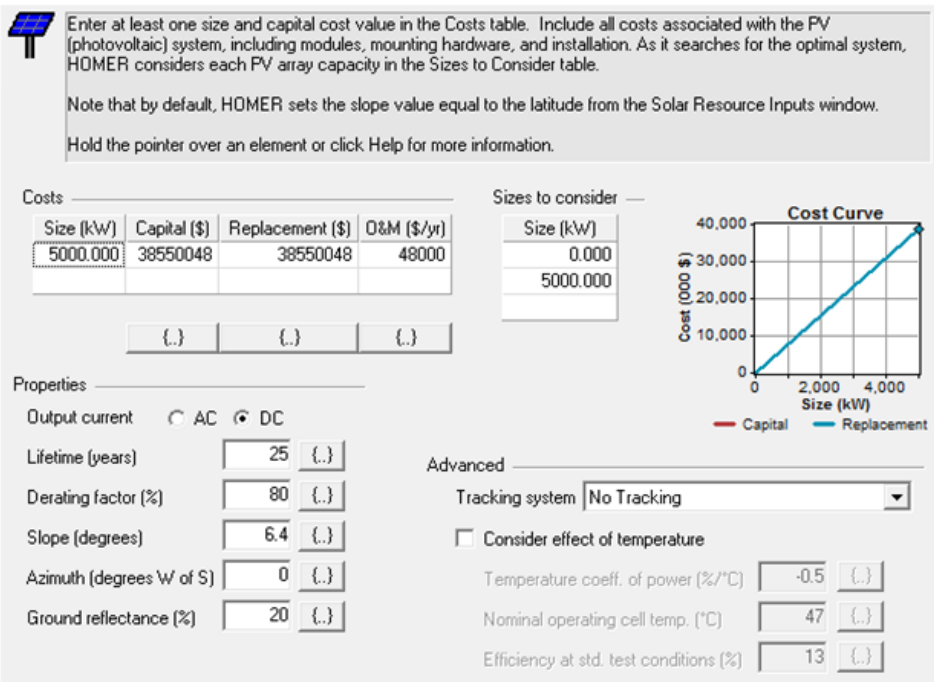

Fig. 5. Parameter input for solar PV generation 


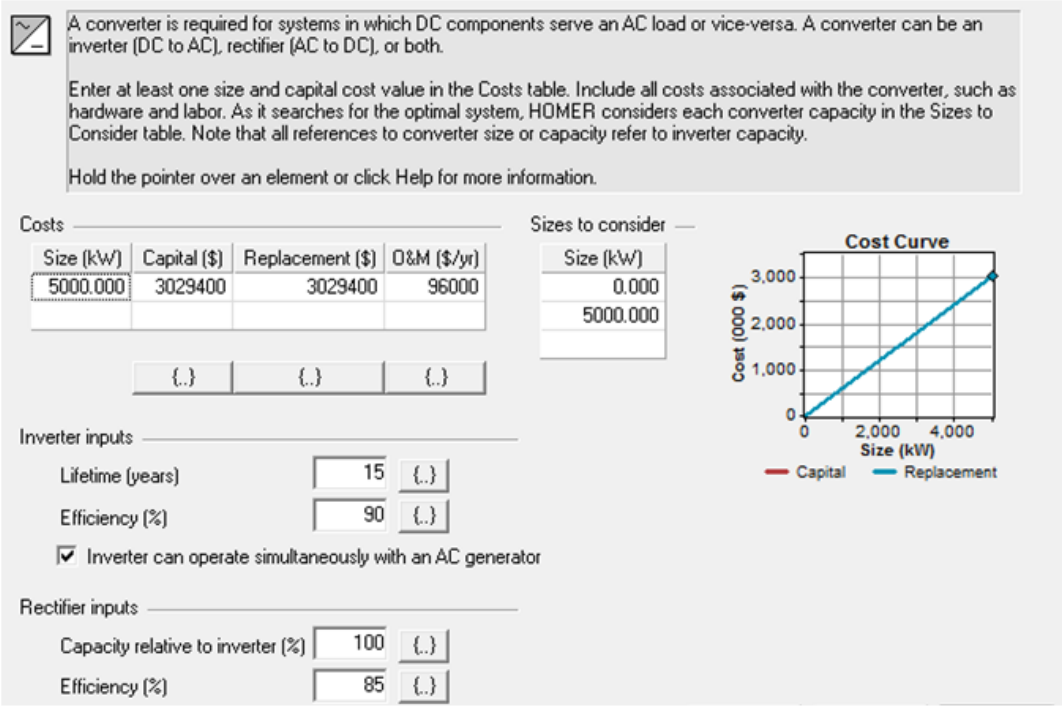

Fig. 6. Parameter inputs for the inverter

Table 2. FiT Rates in Malaysia (KeTTHA, 2011)

\begin{tabular}{|c|c|c|c|}
\hline \multirow[b]{2}{*}{ Description of qualifying renewable energy } & \multicolumn{3}{|c|}{ Fit rates (RM per kWh) } \\
\hline & 2011 & 2012 & 2013 \\
\hline \multicolumn{4}{|l|}{ (a) Basic FiT rates having installed capacity of: } \\
\hline Up to and including $4 \mathrm{~kW}$ & 1.2300 & 1.2300 & 1.1316 \\
\hline Above $4 \mathrm{~kW}$ and up to and including $24 \mathrm{~kW}$ & 1.2000 & 1.2000 & 1.1040 \\
\hline Above $24 \mathrm{~kW}$ and up to and including $72 \mathrm{~kW}$ & 1.1800 & 1.1800 & 1.0856 \\
\hline Above $72 \mathrm{~kW}$ and up to and including $1 \mathrm{MW}$ & 1.1400 & 1.1400 & 1.0488 \\
\hline Above $1 \mathrm{MW}$ and up to and including $10 \mathrm{MW}$ & 0.9500 & 0.9500 & 0.8740 \\
\hline $\begin{array}{l}\text { Above } 10 \mathrm{MW} \text { and up to and including } 30 \mathrm{MW} \\
\text { (b) Bonus Fit rates having the following criteria }\end{array}$ & 0.8500 & 0.8500 & 0.7820 \\
\hline Use as installation in buildings or building & +0.2600 & +0.2600 & +0.2392 \\
\hline Use as building materials & +0.2500 & +0.2500 & +0.2300 \\
\hline Use of locally manufactured or assembled solar PV & +0.0300 & +0.0300 & +0.0276 \\
\hline Use of locally manufactured or assembled solar & +0.0100 & +0.0100 & +0.0092 \\
\hline
\end{tabular}

\section{Inverter Model}

Given that the output signal from solar PV is DC current, installing the inverter to change the DC input to AC output before entering the grid system was necessary. Based on the maximum output from solar PV (5 MW), the inverter capacity was expected to be the same. The proposed lifetime of the inverter is 15 years. Another parameter proposed by HOMER was efficiency, which is $90 \%$, as shown in Fig. 6. The cost for this inverter was RM 3,029,400.00.

\section{Grid Model}

HOMER can be used to model the system used in grid-connected or stand-alone systems. The capacity of this plant was above $1 \mathrm{MW}$ and could reach $10 \mathrm{MW}$. The power plant began to sell energy on January 2013. The FiT approved by SEDA was RM 0.874, as per Table 2 . To secure investments, all of the energy produced by the solar PV plant was allowed to enter the grid without any limit to maximize the income from solar generation.

\section{Analysis of GHG Reduction}

HOMER can simulate GHG reductions of the solar PV plant. In this study, the emission setting was proposed by HOMER. Emission factors for grid power were set by HOMER as $632 \mathrm{~g} / \mathrm{kWh}$ for $\mathrm{CO}_{2}, 2.74 \mathrm{~g} / \mathrm{kWh}$ for $\mathrm{SO}_{2}$ and $1.34 \mathrm{~g} / \mathrm{kWh}$ for $\mathrm{N}_{2} \mathrm{O}$. Based on $\mathrm{GHG}$ simulation results, these values were analyzed to study the $\mathrm{CO}_{2}$ reduction target proposed by the Malaysian government, which is $145,000,000$ tonnes by year 2030 (Mendoca et al., 2009).

\section{Economic Analysis}

The economy presents a crucial function in the development of large scale solar power plants because of the complex interplay of incentives and various supply demand factors that impact the owner. The major components of the system cost include the price of solar panels, inverter and infra work. To analyze economic implications, the total investment required to create a 
solar PV power plant must be determined. To ensure the adherence of our economic analysis to Malaysian economic conditions, actual costs must be obtained and real figures must be presented to investors. In the construction of solar power plants, the material cost of solar panels and inverters is not the only expense. Costs involved in mounting the structure, transformer and high-tension switchgear, as well as land acquisition or management costs, must also be considered. Malaysian Ringgit ( $1 \mathrm{MYR}=0.30$ US Dollar) was used as the main currency for this study. The total actual cost obtained from investors was RM 41,579,448.10. Detailed prices are shown in Table 3 and Fig. 7.

The costs and benefits of the proposed solar PV system throughout its lifetime were analyzed and assessed by HOMER using the following financial indicators.

Net Present Value (NPV) represents the life cycle cost of the system. The calculation assesses all costs occurring within the project lifetime, including initial set-up costs, component replacements within the project lifetime, maintenance and fuel. Future cash flows are discounted to the present. HOMER calculated NPV according to the following Equation 1:

$$
N P V(R M)=\frac{T A C}{C R F}
$$

where, TAC is the total annualized cost (\$) (the sum of the annual costs of each system component). The Capital Recovery Factor (CRF) was calculated as:

$$
C R F=\frac{i(1+i)^{N}}{(1+i)^{N}-1}
$$

where, $\mathrm{N}$ is the number of years and " $\mathrm{i}$ " is the annual real interest rate $(\%)$.

Cost of Energy $(\mathrm{CoE})$ is the cost of generating electricity. The Life Cycle Cost (LCC), unit cost and payback period criteria were used and the LCC was obtained using the formula below:

$$
L C C=C_{\text {capital }}+C_{O \& M}+C_{\text {replacement }}-C_{\text {salvage }}
$$

The capital cost $\left(\mathrm{C}_{\text {capital }}\right)$ of a project includes the initial $\mathrm{C}_{\text {capital }}$ for the equipment, system design and installation. The $\mathrm{C}_{\text {capital }}$ is usually considered as a single payment made on the first year of the project. The maintenance cost $\left(\mathrm{C}_{\mathrm{O} \& \mathrm{M}}\right)$ is the sum of all O\&M costs incurred yearly. Examples for O\&M costs include operator salary, inspections, insurance and property tax. The replacement cost $\left(\mathrm{C}_{\text {replacement }}\right)$ is the sum of equipment replacement costs incurred over the lifetime of the system. A good example of a $\mathrm{C}_{\text {replacement }}$ expense is the battery, which requires replacement once or twice during the entire lifetime of the system.

These costs normally occur at specific predicted years and the entire cost is often covered by the predicted yearly expenses. Finally, the salvage value $\left(\mathrm{C}_{\text {salvage }}\right)$ of a system refers to its net worth in the final year of the life-cycle period. Assigning a $\mathrm{C}_{\text {salvage }}$ of $20 \%$ of the original cost for mechanical equipment that can be moved is a common practice. The $\mathrm{C}_{\text {salvage }}$ can be modified depending on other factors, such as obsolescence and equipment condition [46]. After calculating the LCC, the unit CoE produced by the system can be calculated as follows:

$$
C o E=\frac{L C C}{\sum_{1}^{n} E p v}
$$

Table 3. Detailed cost for $5 \mathrm{MWp}$ solar power generations

\begin{tabular}{llr}
\hline Description & RM & $(\%)$ \\
\hline Management cost & $3,694,156.70$ & 9 \\
Land acquisition & $2,200,000.00$ & 5 \\
Building, infra and civil work & $13,312,500.00$ & 32 \\
Solar modules & $12,100,000.00$ & 29 \\
Inverters & $3,029,400.00$ & 7 \\
Installation cost & $5,423,244.50$ & 13 \\
Electrical equipment and Assc & $1,363,574.90$ & 3 \\
Others (Legal Fees/General) & $456,572.00$ & 1 \\
Total & $41,579,448.10$ & 100 \\
\hline
\end{tabular}

Cost of development $5 \mathrm{MW}$ solar farm power plant

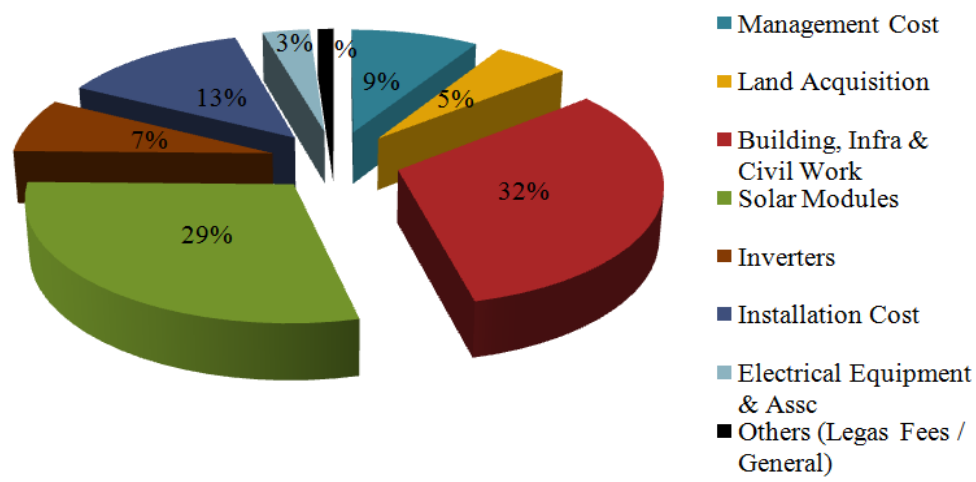

Fig. 7. Percentage of costs in the development of the $5 \mathrm{MWp}$ solar power generation 
The material cost of solar panels and inverters is not the only expense encountered during the construction of solar power plants. Costs involved in construction, such as electrical tools (step-up transformers, high-tension switchgears, or cables), land acquisition and management costs must be considered.

Simple Payback Period (SPP) represents the number of years required for the cash flow to equal the total investment. The basic assumption of the SPP method is that the more quickly the cost of an investment can be recovered, the more desirable the investment is. The equation for SP is given below:

$$
\text { Payback period }=\frac{\text { Initial Investment }}{\text { Cash In Flow Per Period }}
$$

Degression Analysis of FiT in Malaysia, the tariff degression per annum set by SEDA is $8 \%$. The FiT rate is different for each year. In this study, the degression of FiT was estimated by HOMER for two years: For 2014, where the FiT is projected at RM 0.804 and for 2015, where the FiT is projected at RM 0.739 . Degressions of FiT were set as sensitivity values. The analysis using FiT rate after two years, from 2014 to 2015, was performed for comparative purposes; the FiT rates of 2014 and 2015 and the degression of FiT were shown to investors to spark interest in investing in solar PV generation in the next two years. Degression analysis used constant values of capital cost because of the uncertainty in future market prices.

\section{Results and Discussion}

\section{Technical Analysis}

The technical aspect of our study is discussed in this section. Technical indicators were analyzed and solar irradiance, technical performance, energy production and GHG emissions are discussed. The variation in monthly average of solar radiation on the tilted PV modules indicates that solar radiation is minimum during July $\left(4.070 \mathrm{kWh} / \mathrm{m}^{2}\right)$, which reflects a $22.10 \%$ error. The maximum actual solar radiation measurement in March $\left(6.335 \mathrm{kWh} / \mathrm{m}^{2}\right)$ was compared with the simulation results in February $\left(6.134 \mathrm{kWh} / \mathrm{m}^{2}\right)$. The predicted yearly irradiance was $5.27 \mathrm{kWh} / \mathrm{m}^{2}$ and the measured value was $6.66 \mathrm{kWh} / \mathrm{m}^{2}$. Comparison of solar resource inputs from HOMER and the measured irradiance shows that solar radiation is maximum from February to April and minimum from May to July. The average yearly solar irradiance error percentage was $20.88 \%$, as determined by the HOMER output. All comparisons of solar radiation are summarized in Table 4 and Fig. 8.

To compare the measured and predicted outputs of the solar plant, the normalized energy yield $(\mathrm{kWh} / \mathrm{kWp})$ was calculated. The measured total normalized energy output for the year 2013 was $1358.11 \mathrm{kWh} / \mathrm{kW}_{\mathrm{p}}$, whereas the predicted yearly output was $1390.22 \mathrm{kWh} / \mathrm{kW}_{\mathrm{p}}$. Results of the estimation of energy yield using HOMER software were in close agreement with the actual measured results; an uncertainty of only $2.31 \%$ was obtained. Comparisons of technical performance are summarized in Table 5.

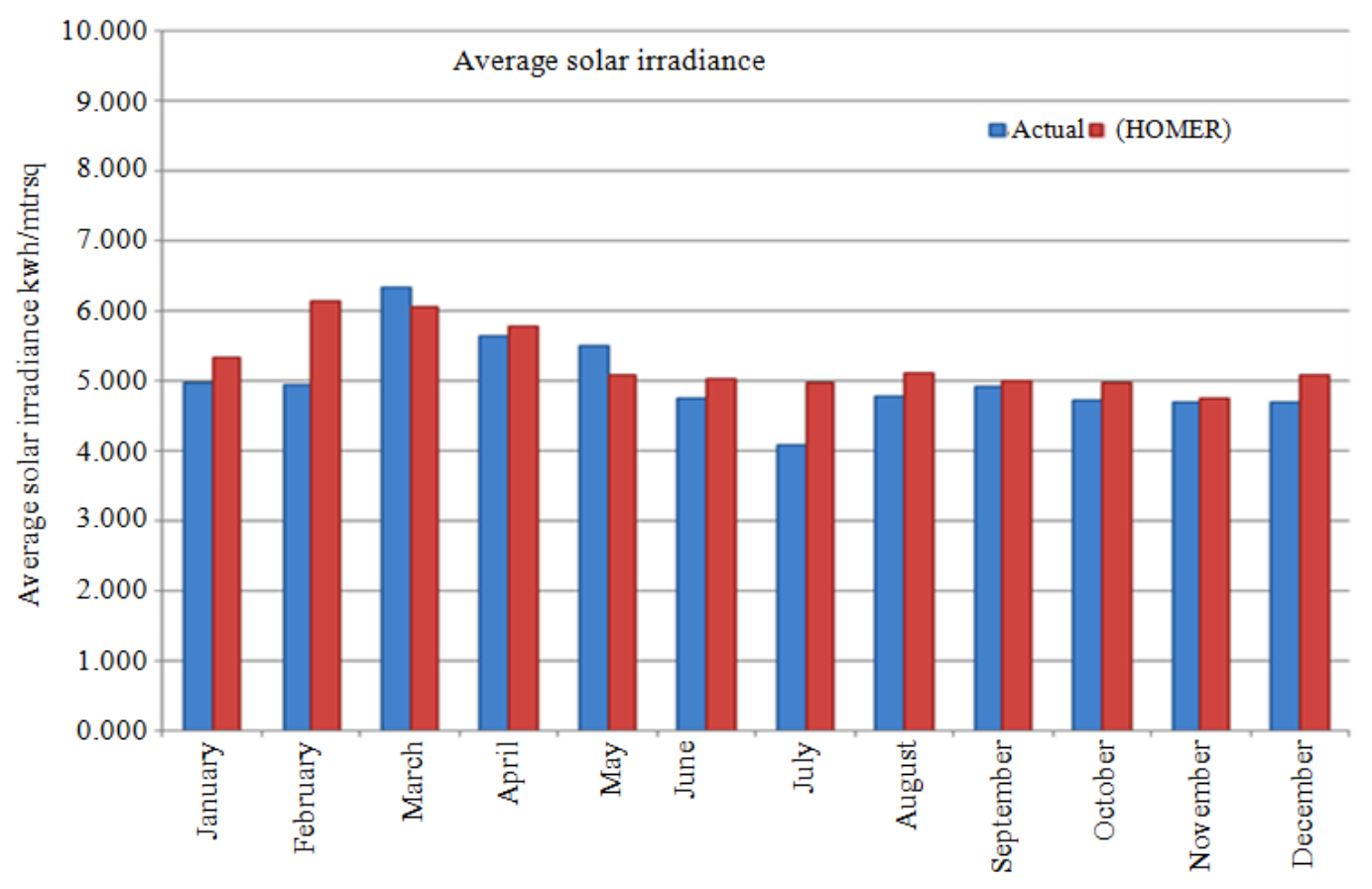

Fig. 8. Actual solar irradiance data versus simulation results 
$(\mathrm{kWh})$ Energy production yearly

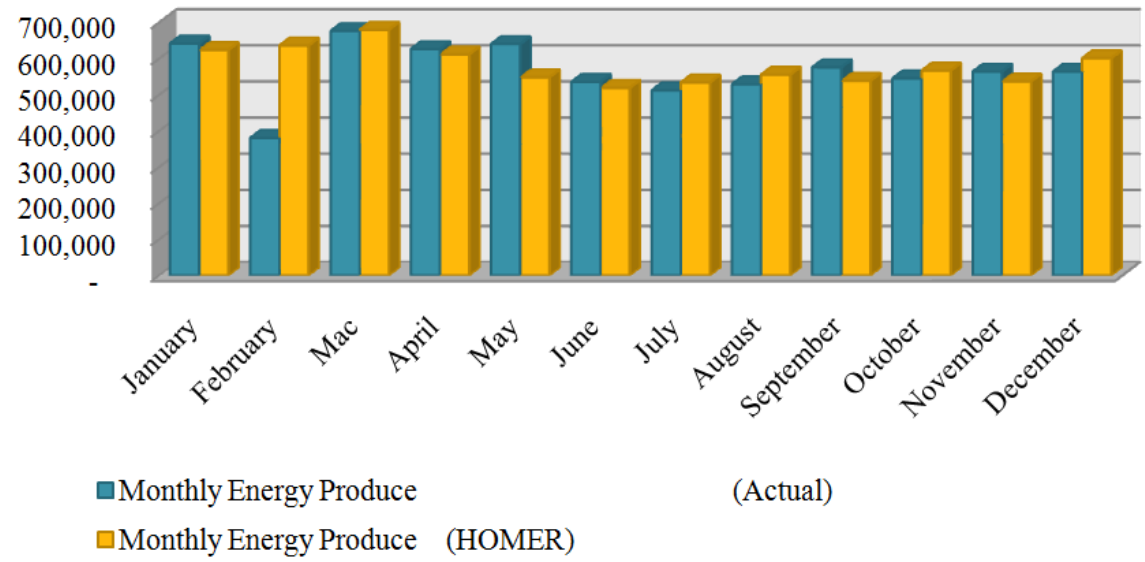

Fig. 9. Bar chart of energy production

Table 4. Summary of solar radiation

\begin{tabular}{lccr}
\hline Month & Actual $\left(\mathrm{kWh} / \mathrm{m}^{2}\right)$ & $($ HOMER $)\left(\mathrm{kWh} / \mathrm{m}^{2}\right)$ & Error $(\%)$ \\
\hline January & 4.956 & 5.329 & -7.53 \\
February & 4.941 & 6.134 & -24.15 \\
March & 6.335 & 6.053 & 4.46 \\
April & 5.640 & 5.759 & -2.11 \\
May & 5.505 & 5.078 & 7.76 \\
June & 4.749 & 5.010 & -5.50 \\
July & 4.070 & 4.970 & -22.10 \\
August & 4.774 & 5.106 & -6.95 \\
September & 4.899 & 4.994 & -1.93 \\
October & 4.704 & 4.978 & -5.81 \\
November & 4.692 & 4.757 & -1.38 \\
December & 4.692 & 5.083 & -8.33 \\
Total annual & 59.959 & 63.251 & 20.88 \\
Monthly average & 6.660 & 5.270 & \\
\hline
\end{tabular}

Table 5. Summary of technical performance

\begin{tabular}{lll}
\hline Technical parameters & Actual data & HOMER results \\
\hline Average annual power output $(\mathrm{kWh} /$ year $)$ & $6,790,560.00$ & $6,951,076.00$ \\
Peak power of the install PV $(\mathrm{kWp})$ & 5000 & 5000 \\
Yield factor $(\mathrm{kWh} / \mathrm{year} / \mathrm{kWp})$ & $1,358.11$ & $1,390.22$ \\
Capacity factor $(\mathrm{YF} / 8760)$ & $15.50 \%$ & $15.87 \%$ \\
\hline
\end{tabular}

Table 6. Summary of energy production

\begin{tabular}{lllr}
\hline Month & Monthly energy produce $($ Actual $)(\mathrm{kWh})$ & Monthly energy produce $($ HOMER) $(\mathrm{kWh})$ & Error $(\%)$ \\
\hline January & 641,870 & 623,771 & 2.82 \\
February & 380,500 & 636,260 & -67.22 \\
March & 676,260 & 679,757 & -0.52 \\
April & 626,260 & 611,631 & 2.34 \\
May & 640,230 & 548,205 & 14.37 \\
June & 535,610 & 518,798 & 3.14 \\
July & 512,120 & 534,042 & -4.28 \\
August & 529,020 & 555,548 & -5.01 \\
September & 575,810 & 538,527 & 6.47 \\
October & 545,220 & 566,801 & -3.96 \\
November & 563,830 & 536,680 & 4.82 \\
December & 563,830 & 601,056 & -6.60 \\
Total Annual & $6,790,560$ & $6,951,076$ & -2.36 \\
\hline
\end{tabular}


The measured monthly normalized yield was highest for March (135.25 kWh/kWp) and the predicted normalized yield was maximum for March (135.95 $\mathrm{kWh} / \mathrm{kWp}$ ). Therefore, an error of $0.518 \%$ was obtained. The plant supplied $6.79 \mathrm{GWh}$ of energy during the year 2013, whereas the total annual energy yield predicted by HOMER was $6.95 \mathrm{GWh}$, which indicates an error of $2.35 \%$. All comparisons of energy production are summarized in Table 6 and Fig. 9.

Calculations of the annual reduction in estimated GHG emissions yielded values of 4,393,080 kg/year for $\mathrm{CO}_{2}, 19,046 \mathrm{~kg} /$ year for $\mathrm{SO}_{2}$ and $9,314 \mathrm{~kg} /$ year for $\mathrm{N}_{2} \mathrm{O}$. Based on this yearly reduction of GHG emission for the twenty one year, the objective of Malaysia target in $\mathrm{CO}_{2}$ reduction in year 2030 is not achievable which is $57.17 \%$ from $145,000,000$ tons when this plant reach 2030.

\section{Economic Analysis}

The economic aspect of our study is discussed in this section. Analyzing the economic aspect of power generation is important because it gives investors the necessary information for gauging the success of renewable energy investments in Malaysia. Here, economic indicators, including the NPV and $\mathrm{CoE}$ and SPP period are discussed.

\section{Net Present Value and Cost of Energy}

The NPV for this project is RM 26,628,810.00 and its CoE is RM 0.329/kWh, as shown in Fig. 10. A negative
NPV is an indicator of the total profit of this project. Based on our analysis, we believe that the project will be profitable and attract investors to invest in solar PV generation. A negative $\mathrm{CoE}$ indicates income as renewable energy production for every $\mathrm{kWh}$.

\section{Simple Payback Period}

As described previously, the payback period for solar power generation is 10 years, as indicated in Fig. 11 and 12 and Table 7. The cash inflow is negative for the first nine years to recover the initial capital cost. Investments begin to turn a profit starting from the tenth year to the twenty-fifth year.

\section{Sensitivity Analysis}

To explore possible discrepancies in the results caused by key parameter variations, sensitivity analysis was performed for important parameters, such as FiT degression, initial investment cost, project lifetime and electricity export cost. CoE production varied between 0.194 and $0.329 \mathrm{RM} / \mathrm{kWh}$ with a FiT degression rate of $8 \%$ per year. Results of sensitivity analysis of NPV varied significantly in terms of FiT rate (e.g., RM 26,628,810.00, RM 20,958,466.00 and RM 15,693,144.00), as shown in Fig. 13. The FiT degression rate implies that investor profits will eventually decline. This decrease in profit will surely cause anxiety to prospective investors in solar PV generation in the years following 2013.

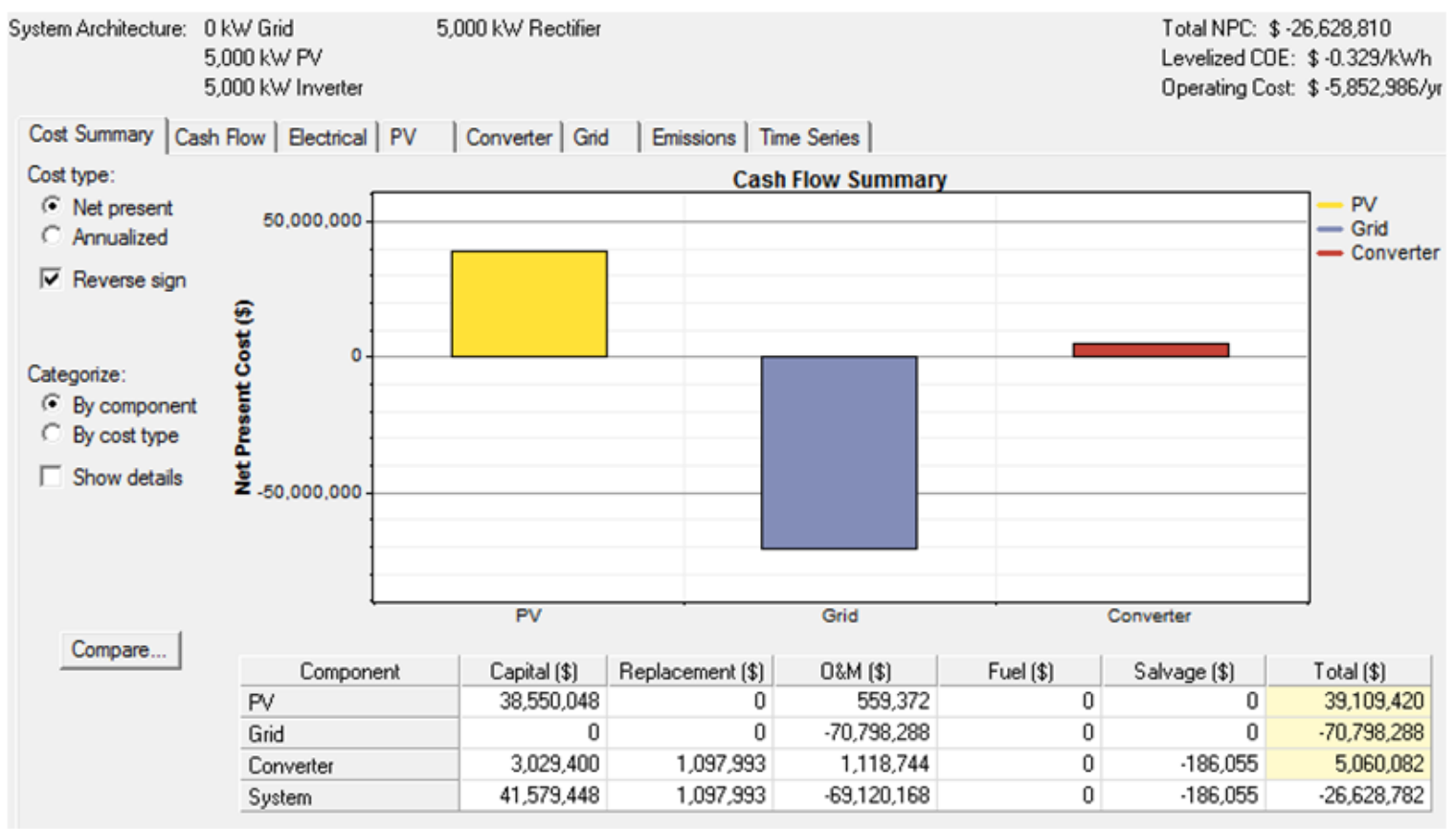

Fig. 10. Net present value analysis and cost of energy (Malaysian Ringgit, RM) 


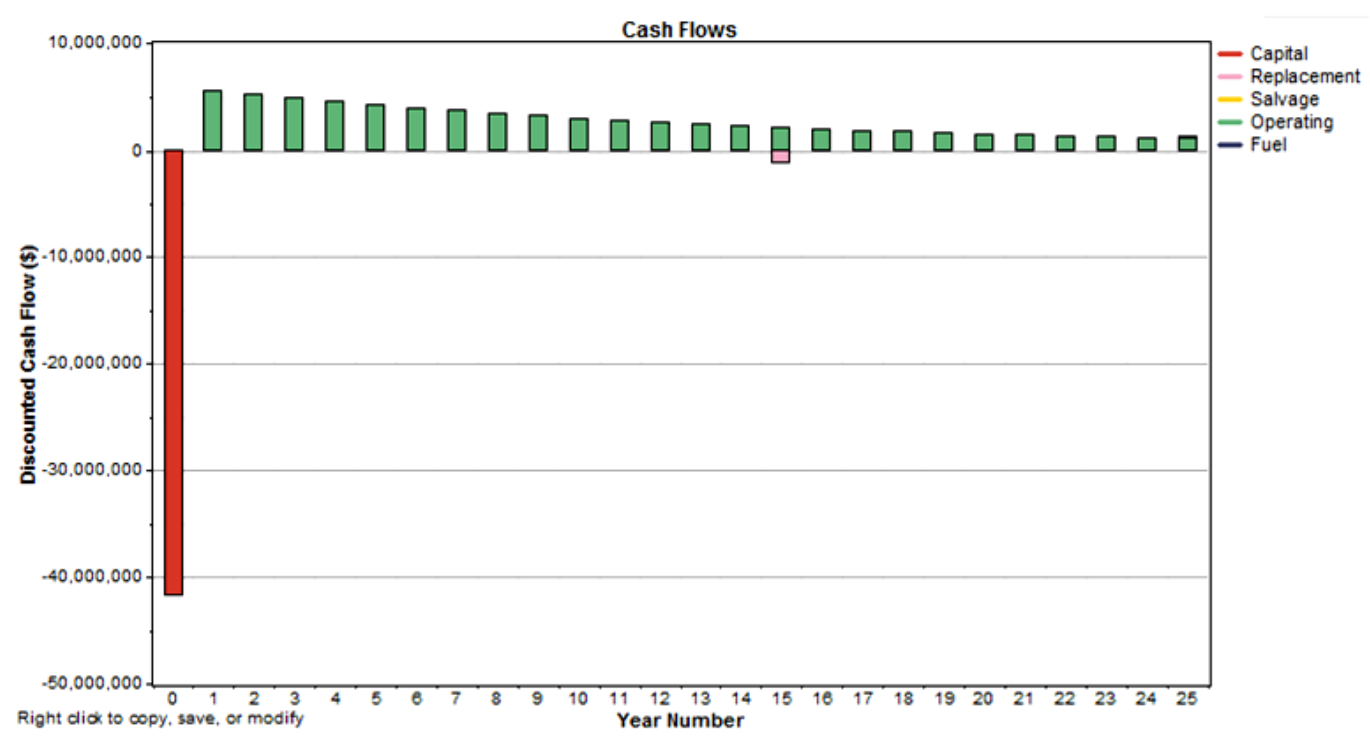

Fig. 11. Discounted of cash flow

$\mathrm{RM}$

Payback period

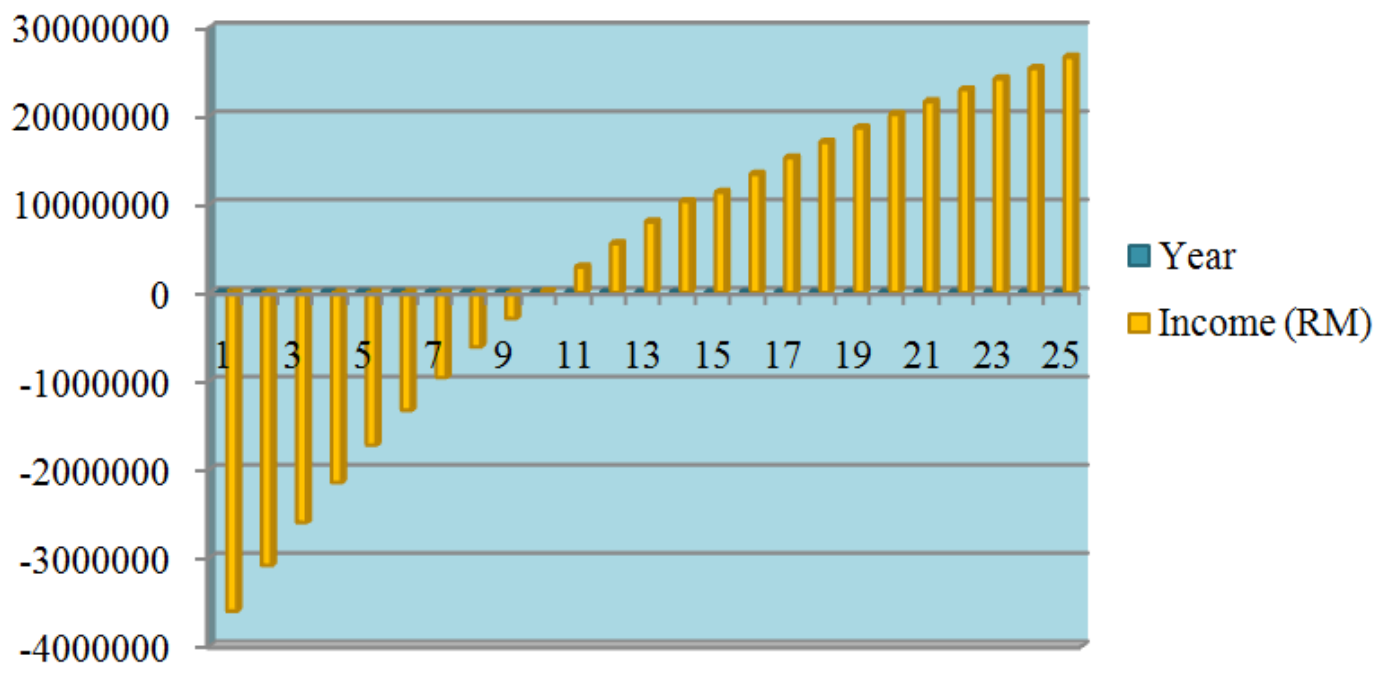

Fig. 12. Simple payback period analysis (Malaysian Ringgit, RM)

\begin{tabular}{|c|c|c|c|c|c|c|c|c|}
\hline $\begin{array}{c}\text { Rate } 1 \\
\text { Sellback }(\mathrm{S} / \mathrm{kWh})\end{array}$ & (1)利田园 & $\begin{array}{l}\mathrm{PV} \\
(\mathrm{kW})\end{array}$ & $\begin{array}{l}\text { Conv. } \\
(\mathrm{kW})\end{array}$ & $\begin{array}{l}\text { Grid } \\
(\mathrm{kW})\end{array}$ & $\begin{array}{l}\text { Initial } \\
\text { Capital }\end{array}$ & $\begin{array}{l}\text { Operating } \\
\text { Cost (S/yr) }\end{array}$ & $\begin{array}{l}\text { Total } \\
\text { NPC }\end{array}$ & $\left|\begin{array}{c}\mathrm{COE} \\
(\mathrm{S} / \mathrm{kWh})\end{array}\right|$ \\
\hline 0.874 & & 5000 & 5000 & & S 41,579,448 & $-5,852,986$ & S-26,628,810 & -0.329 \\
\hline 0.804 & & 5000 & 5000 & & S 41.579.448 & -5.366 .411 & S-20.958.466 & -0.259 \\
\hline 0.739 & & 5000 & 5000 & & S 41,579,448 & -4.914 .591 & S $-15,693,144$ & -0.194 \\
\hline
\end{tabular}

Fig. 13. Sensitivity analysis based on degression of FiT

To acquire a better understanding of the solar power plant performance, performance parameters evaluated for the Perlis solar power plant were compared with the reported performance parameters of solar power plants at various locations (Table 8). The annual average energy yield of the solar power after twelve months of continuous operation is $1390.22 \mathrm{kWh} / \mathrm{kWp}$. This annual average yield is comparable with the annual average energy yield of solar power plant systems at other locations, which confirms the suitability of solar power generation in Perlis. 
M. Pauzi M. Kassim et al. / American Journal of Engineering and Applied Sciences 2015, 8 (2): 210.222 DOI: 10.3844/ajeassp.2015.210.222

Table 7. Simple payback period analysis (Malaysian Ringgit, RM)

\begin{tabular}{llllll}
\hline Year & 1 & 2 & 3 & 4 & 5 \\
\hline RM/Year & $5,543,215.00$ & $5,180,575.00$ & $4,841,658.00$ & $4,524,914.00$ & $4,228,891.00$ \\
Cumulative (RM) & $5,543,215.00$ & $10,723,790.00$ & $15,565,448.00$ & $20,090,362.00$ & $24,319,253.00$ \\
Year & 6 & 7 & 8 & 9 & 10 \\
RM/Year & $3,952,235.00$ & $3,693,677.00$ & $3,452,035.00$ & $3,226,200.00$ & $3,015,140.00$ \\
Cumulative (RM) & $3,952,235.00$ & $7,645,912.00$ & $11,097,947.00$ & $14,324,147.00$ & $17,339,287.00$ \\
Year & 11 & 12 & 13 & 14 & 15 \\
RM/Year & $2,817,888.00$ & $2,633,540.00$ & $2,461,252.00$ & $2,300,236.00$ & $1,051,760.00$ \\
Cumulative (RM) & $44,476,428.00$ & $47,109,968.00$ & $49,571,220.00$ & $51,871,456.00$ & $52,923,216.00$ \\
Year & 16 & 17 & 18 & 19 & 20 \\
RM/Year & $2,009,115.00$ & $1,877,677.00$ & $1,754,838.00$ & $1,644036.00$ & $1,532,744.00$ \\
Cumulative (RM) & $54,932,331.00$ & $56,810,008.00$ & $58,564,846.00$ & $60,204,882.00$ & $61,737,626.00$ \\
Year & 21 & 22 & 23 & 24 & 25 \\
RM/Year & $1,432,471.00$ & $1,338,758.00$ & $1,251,175.00$ & $1,169,323.00$ & $1,278,879.00$ \\
Cumulative (RM) & $63,170,097.00$ & $64,508,855.00$ & $65,760,030.00$ & $66,929,353.00$ & $68,208,232.00$ \\
\hline
\end{tabular}

Table 8. Performance comparison of PV systems in different countries

\begin{tabular}{lrll}
\hline Location & Rated capacity $(\mathrm{kWp})$ & Energy yield $(\mathrm{kWh} / \mathrm{kWp})$ & References \\
\hline Perlis, Malaysia & 5000.00 & 1358.11 & Present study \\
Crete, Greece & 171.36 & 1336.40 & (Tiwari and Dubey, 2010) \\
Dublin, Ireland & 1.72 & 885.10 & (Ayompe et al., 2011) \\
Khatkar-Kalan, India & 190.00 & 812.76 & (Mondal and Sadrul Islam, 2011) \\
Warsaw, Poland & 1.00 & 830.00 & (Pietruszko and Gradzki, 2003) \\
\hline
\end{tabular}

A brief analysis of such studies is summarized in Table 8 . Based on our comparison, we conclude that Malaysia has the best potential for solar PV power generation among the four countries studied (Greece, Ireland, India and Poland).

\section{Conclusion}

In this study, performance and economic effects of a 5 MWp solar PV plant installed at Perlis, Malaysia, was conducted. Comparison of the energy yield of solar power plant systems in Malaysia with other systems installed at different locations worldwide shows that the energy yield of the solar PV plant in Malaysia (1358.11) $\mathrm{kWh} / \mathrm{kWp}$ is higher than those of other countries. The comparative study confirms the suitability of Malaysia as a solar power plant location. Estimations of energy yield using HOMER software are in close agreement with the actual measured results and showed an error of $2.31 \%$. The FiT degression rate $(8 \%)$ will reduce income from solar power generation according to our sensitivity analysis. This predicted income reduction may worry investors and prevent them from investing in solar power generation. The lack of investment will result in failure to achieve the objectives of the Malaysian government, particularly in the renewable energy sector.

\section{Author's Contributions}

M. Pauzi M. Kassim: Participated in all experiments, coordinated the data-analysis and contributed to the writing of the manuscript.

Karam M. Al-Obaidi: Participated in all experiments, coordinated the data-analysis and contributed to the writing of the manuscript.

M. Arkam C. Munaaim: Participated in all experiments, coordinated the data-analysis and contributed to the writing of the manuscript.

Abd. Mokhti Salleh: Designed the research plan and organized the study.

\section{Ethics}

We guarantee the truth of all data and the originality of this paper.

\section{References}

APEC, 2009. APEC Energy and Demand Supply Outlook. 4th Edn., Ecomic Review.

Ayompe, L.M., A. Duffy, S.J. McCormack and M. Conlon, 2011. Measured performance of a $1.72 \mathrm{~kW}$ rooftop grid connected photovoltaic system in Ireland. Energy Conver. Manage., 52: 816-825. DOI: 10.1016/j.enconman.2010.08.007

Bhattacharjee, S. and A. Dey, 2014. Techno-economic performance evaluation of grid integrated PVbiomass hybrid power generation for rice mill. Sustainable Energy Technol. Assess., 7: 6-16. DOI: $10.1016 /$ j.seta.2014.02.005

BP, 2011. BP stastical review of world energy outlook. British Petroleum.

Canale, M., I. Fagiano and M. Milanese, 2009. KiteGen: A revolution in wind energy generation. Energy, 34: 355-361. DOI: 10.1016/j.energy.2008.10.003 
Chamboulegron, I., 1986. A third world view of the photovoltaic market. Solar Energy, 36: 381-386. DOI: 10.1016/0038-092X(86)90085-X

Chua, S.C., T.H. Oh and W.W. Goh, 2011. Feed-in tariff outlook in Malaysia. Renewable Sustainable Energy Rev., 15: 705-712.

Daud, M., 2010. Future for nuclear in Malaysia, presented at mosti energy forum Malaysia, sheraton imperial. Kuala Lumpur, Malaysia.

Enslin, J.H.R., 1990. Maximum power point tracking: A cost saving necessity in solar energy systems. Proceedings of the 16th Annual Conference of IEEE Industrial Electronics Society, Nov. 27-30, IEEE Xplore Press, Pacific Grove, CA pp: 1073-1077. DOI: 10.1109/IECON.1990.149286

GPS, 2012. Cypark integrated energy park in Malaysia starts supplying solar power to grid. GPS.

Henrion, T., K. Ponweiser, D. Band and T. Telgen, 2013. Dynamic simulation of a solar power plant steam generation system. Simulat. Modell. Practice Theory, 33: 2-17.

DOI: $10.1016 /$ j.simpat.2011.12.009

Hussein, K.H., I. Muta and T. Hoshino and M. Osakada, 1995. Maximum photovoltaic power tracking: An algorithm for rapidly changing atmospheric conditions. IEE Proc. Generat. Transmiss. Distrib., 142: 59-64. DOI: 10.1049/ip-gtd:19951577

KeTTHA, 2011. Handbook on the Malaysia feed in tariff for promotion of renewable energy. KeTTHA, Sustainble Energy Developement Authorot.

Mekhilef, S., A. Safari, W.E.S. Mustaffa, R. Saidur and R. Omar et al., 2012. Solar energy in Malaysia: Current state and prospects. Renewable Sustainable Energy Rev., 16: 386-396.

DOI: $10.1016 /$ j.rser.2011.08.003

Mendoca, M., D. Jacobs and B.K. Sovacool, 2009. Powering the Green Economy: The Feed-in Tariff Handbook. 1st Edn., Earthscan, London, ISBN-10: 1844078574, pp: 208.
Mercure, J.F. and P. Salas, 2012. An assessement of global energy resource economic potentials. Energy, 46: 322-336. DOI: 10.1016/j.energy.2012.08.018

MP, 2011. Global challenges facing humanity. Millennium Project.

NEB, 2008. Ministry of energy, green technology and water. National Energy Balance, Malaysia.

Mondal, M. and A.K.M. Sadrul Islam, 2011. Potential and viability of grid-connected solar PV system in Bangladesh. Renewable Energy, 36: 1869-1874. DOI: 10.1016/j.renene.2010.11.033

Penick, T. and B. Louk, 1998. Photovoltaic power generation. Report submitted to Gale Greenleaf.

Pietruszko, S.M. and M. Gradzki, 2003. Performance of a grid connected small PV system in Poland. Applied Energy, 74: 177-184. DOI: 10.1016/S0306-2619(02)00144-7

Quesada, B., C. Sanchez, J. Canada, R. Royo and J. Paya, 2011. Experimental results and simulation with TRNSYS of a $7.2 \mathrm{kWp}$ grid-connected photovoltaic system. Applied Energy, 88: 1772-1783. DOI: 10.1016/j.apenergy.2010.12.011

Sharma, V. and S.S. Chandel, 2013. Performance analysis of a $190 \mathrm{kWp}$ grid interactive solar photovoltaic power plant in India. Energy, 55: 476-485. DOI: 10.1016/j.energy.2013.03.075

Sick, F. and T. Erge, 1996. Photovoltaics in Buildings: A Design Handbook for Architects and Engineers. 1st Edn., James and James, London, ISBN-10: 1873936591, pp: 287.

Tiwari, G.N. and S. Dubey, 2010. Fundamentals of Photovoltaic Modules and Their Applications. 1st Edn., Royal Society of Chemistry, Cambridge, U.K., ISBN-10: 1849730202, pp: 402.

Zweibel, K., 1990. Harnessing Solar Power: The Photovoltaics Challenge. 1st Edn., Plenum Press, New York, ISBN-10: 0306435640, pp: 319. 